\title{
Endozoochorous dispersal of seeds of weedy rice (Oryza sativa L.) and barnyardgrass (Echinochloa crus-galli L.) by cattle
}

\author{
João Luis Carricio Viero ${ }^{1}$ Carlos Eduardo Schaedler $^{2 *}$ Eduardo Bohrer de Azevedo ${ }^{2}$ \\ João Vitor Ail dos Santos ${ }^{1}$ Ricardo de Mello Scalcon ${ }^{1}$ Diego Bitencourt de David ${ }^{3}$ \\ Fabiane Quevedo da Rosa ${ }^{4}$
}

${ }^{1}$ Universidade Federal do Pampa (UNIPAMPA), Itaqui, RS, Brasil.

${ }^{2}$ Universidade Federal do Pampa (UNIPAMPA), 97650-000, Itaqui, RS, Brasil. E-mail:caduschaedler@yahoo.com.br. "Corresponding author. ${ }^{3}$ Departamento de Diagnóstico e Pesquisa Agropecuária (DDPA), São Gabriel, RS, Brasil.

${ }^{4}$ Universidade Federal do Pampa (UNIPAMPA), Uruguaiana, RS, Brasil.

ABSTRACT: The objective of this study was to evaluate endozoochory dispersal, recuperation, and germination of weedy rice (Oryza sativa L.) and barnyardgrass (Echinochloa crus-galli L.) seeds passed through the digestive system of cattle. The experiment was divided into two phases: first, the daily seed recuperation rate was determined after passing through the digestive system of six steers. Each animal was dosed individually with 1000 weedy rice seeds and 13,818 barnyardgrass seeds, and these seeds were subsequently collected from feces. In the second phase, seed germination and emergence rate after passing or not passing through the digestive system of cattle were determined in two types of substrates (fecal plaque and soil) in a $2 \times 2$ factorial design. Seed recuperation in feces showed sigmoid behavior with maximum recovery on the second day after dosage. The recuperation of the species in the feces was $50.9 \%$ and $23.4 \%$ for weedy rice and barnyardgrass, respectively, which shows that both have potential endozoochory dispersal. However, seed germination of these species reduced after they passed through the digestive system, and they presented inferior emergence in the fecal plaque compared to the soil. The quarantine period for animals that ingest weedy rice and barnyardgrass seeds should be at least 6 and 7 days, respectively.

Key words: endozoochory, feces, paddy rice, seed ingestion, ruminants.

Dispersão endozoocórica de sementes de arroz daninho (Oryza sativa L.) e capim-arroz (Echinochloa crus-galli L.) por bovinos

RESUMO: O objetivo deste trabalho foi avaliar a dispersão endozoocórica, recuperação e germinação de sementes de arroz daninho (Oryza sativa L.) e capim-arroz (Echinochloa crus-galli L.) passadas pelo sistema digestivo de bovinos. O experimento foi dividido em duas fases: primeiramente determinou-se a taxa de recuperação diária das sementes após passagem pelo sistema digestivo de seis bovinos. Foram dosadas individualmente 1000 sementes de arroz daninho e 13818 sementes de capim-arroz para cada animal e posteriormente coletadas nas fezes. $\mathrm{Na}$ segunda fase foi determinada a taxa de germinação e emergência de sementes com e sem passagem pelo sistema digestivo de bovinos em dois tipos de substratos (placa fecal ou solo) em delineamento fatorial $2 \times 2$. A recuperação de sementes nas fezes apresentou comportamento sigmoide com máxima recuperação no $2^{\circ}$ dia após dosagem. A recuperação nas fezes foi de 50,9\% e 23,4\%, para arroz daninho e capim-arroz, o que demonstra que ambas apresentam potencial de dispersão endozoocórica. Porém, a germinação de sementes destas espécies reduziu ao passar pelo sistema digestivo, e na placa fecal apresentou emergência inferior em comparação ao solo. O periodo de quarentena para animais que ingerirem sementes de arroz daninho e capim-arroz deve ser de no mínimo 6 e 7 dias, respectivamente.

Palavras-chave: arroz irrigado, endozoocoria, fezes, ingestão de sementes, ruminantes.

\section{INTRODUCTION}

Among the weed species that limit the productivity of irrigated rice, weedy rice (Oryza sativa L.) (GALON et al., 2012) and barnyardgrass (Echinochloa spp.) (AGOSTINETTO et al., 2010) are of particular importance. These species are reported nearly all riceproducing regions. Morphophysiological similarity between cultivated rice and these weeds represents a limiting factor in their control (LAMEGO et al., 2004).

The main form of control for these species is the use of chemicals (SOSBAI, 2016); however, in both species, biotypes resistant to the imidazolinone class of herbicides have already evolved (MENEZES et al., 2009). These researchers reported that $55.7 \%$ of rice fields in southern Brazil were colonized by resistant biotypes of $O$. sativa. Furthermore, the frequent use of acetolactate synthase (ALS)-inhibiting herbicides has promoted the evolution of biotypes of Echinochloa spp. Resistant to herbicides with this mechanism of action (MATZENBACHER et al., 2015).

In the case of integrated crop-livestock systems, a proportion of the area used to cultivate rice may also be used for raising cattle. Animals are 
grazed on areas with crop residues of paddy rice during the postharvest period until tillage for the following crop season, or during the fallow season. In southern Brazil, the use of rice crop residues after grain harvesting and plant regrowth is important for ruminant feeding in autumn (MARQUES \& DO COUTO, 2010). In addition, areas of rice fallow are commonly used for animal grazing in summer. However, the presence of these animals postharvest or during the fallow season may enhance the endozoochory of weeds, which are subsequently deposited in feces (DEMINICIS et al., 2009a).

Conversely, passage of seeds through the digestive system of ruminants may potentially decrease seed dispersal and germination. Some authors have reported that, after passage through the digestive tract, the germination of grass species generally tends to decrease linearly with rumen retention time, which can be considered as a benefit of the integrated croplivestock system (OCUMPAUGH \& SWAKON, 1993; SIMÃO NETO et al., 1987).

Zoochory is a form of dispersal primarily studied in forage species with respect to its importance in natural re-sowing in the renovation and persistence of species used as pasture (FISCHER et al., 1996). Although, in this regard, few reports on weeds have been published, BENVENUTI (2007) indicates that endozoochory accounts for $1.5 \%$ of seed dispersal, which may be even higher in the case of herbicideresistant biotypes of weeds. Thus, weed seeds may survive passage through the digestive system of animals and may be dispersed in different areas (GARDENER et al., 1993).

From the perspective of the foregoing considerations, the objective of this study was to assess the extent $O$. sativa and Echinochloa crusgalli endozoochory by examining seed recovery and germination after passage through the digestive system of cattle.

\section{MATERIAL AND METHODS}

The experiment was conducted in two stages. The first was performed near the Forage Research Center (Centro de Pesquisa em Forrageiras; coordinates 30 $21^{\prime} \mathrm{S}$ and $54^{\circ} 16^{\prime} \mathrm{W}$ ) in the city of São Gabriel-RS, and the second at the Federal University of Pampa (Universidade Federal do Pampa - Unipampa; coordinates $29^{\circ} 12^{\prime} \mathrm{S}$ and $56^{\circ} 18^{\prime} \mathrm{W}$ ), Campus Itaqui-RS, from July 2015 to November 2016. Seeds of weedy rice and barnyardgrass biotypes were collected from surviving plants following the application of ALS-inhibiting herbicides in paddy rice areas in the south of Brazil.
To assess endozoochory, six Hereford bullocks, with a mean age of 2 years and 6 months and mean weight of $400 \mathrm{~kg}$, were maintained in stalls for metabolic assays. Animals remained in the stalls for 15 days, during the first 9 days of which they were allowed to adapt to the site and diet. The diet consisted of fresh forage collected from native grassland, and sufficient quantities of fresh forage free of both study weed species were provided to the meet the animals' nutritional requirements. On the $9^{\text {th }}$ day, each bullock was provided at different periods with seeds (1000 weedy rice and 13818 barnyardgrass seeds) using a flexible feeding tube, manually inserted through the glottis. The number of seeds provided to the animals was estimated based on the average seed yield of three plants of each species. Treatments were based on seed recovery periods from cattle feces, at 24 hour-intervals after dosage, totaling six recovery periods (days), with each animal representing a single replicate.

For total fecal collection, bullocks were fitted with polyvinyl chloride (PVC) saddles and bags. Bags were changed three times a day, due to the accumulation of feces. The feces of each animal collected over a 24-hour period were mixed and 50\% of the homogeneous sample was used for weedy rice analysis and a further $10 \%$ for barnyardgrass analysis. After separating the seeds in the feces, the results were converted to numbersper total feces collected. Samples were then washed with running water through a 2-mm-mesh sieve to separate the weedy rice seeds and through a 1-mm-mesh sieve to separate the barnyardgrass seeds. The recovered seeds were stored in labeled plastic containers and refrigerated at $6^{\circ} \mathrm{C}\left( \pm 2^{\circ} \mathrm{C}\right)$ and $85 \%$ relative air humidity.

During the second stage of the experiment, seeds were counted, pre-dried and germinated according to the day of animal recovery. Seed germination papers moistened with water 2.5 times their weight were incubated in a biochemical oxygen demand germination chamber at $26^{\circ} \mathrm{C}$ under a 12 hour photoperiod. In addition to recovered seeds, a control seed germination test (using seeds that had not passed through the digestive system) was performed using four 50 -seed replicates. The first count was made on the $5^{\text {th }}$ day for weedy rice and on the $4^{\text {th }}$ day for barnyardgrass, and a final count was made on the $14^{\text {th }}$ day. The other procedures, such as standard or non-standard seedling characterization, followed the recommendations of the Seed Analysis Rules (Regras de Análise de Sementes; BRASIL, 2009).

To assess the emergence of recovered seeds in both substrates (soil and dung), we used 
eight 20-L trays, filled with sieved soil and fresh dung collected from bullocks, that had been maintained in confinement, free from both study weed species. The trays were subdivided into four quadrants, and the replicates were allocated in a completely randomized design. Treatments were the substrates tested, and assesments were performed every 48 hours, counting the number of seedlings that had emerged. In addition to recovered seeds, weedy rice and barnyardgrass seeds that had not passed through the digestive system were used as controls subjected to the same conditions. Data were analyzed using an analysis of variance (ANOVA; $\mathrm{P} \leq 0.05$ ). When significant differences were detected, the software Sigma Plot 10.0 was used for regression analysis and curve fitting. The least significant difference (LSD) Fisher test $(\mathrm{P} \leq 0.05)$ was applied to assess seed germination as a function of substrate (dung and soil).

\section{RESULTS AND DISCUSSION}

For both weedy rice and barnyardgrass, the average number of recovered seeds showed a sigmoidal behavior from the $2^{\text {nd }}$ day (Figures $1 \mathrm{~A}$ and B). Weedy rice showed a mean recovery of $50.9 \%$ of the quantity fed to animals, whereas barnyardgrass had a lower recovery of $23.4 \%$ of the ingested seeds. For endozoochory, seed coating-related characteristics are important because seeds with resistant coats are more likely to survive passage through the digestive system of animals (DEMINICIS et al., 2009b). Thus, we assume that the higher recovery of weedy rice seeds compared with barnyardgrass seeds is possibly attributable to the fact that the seed protective structures of the former are more resistant than those of the latter, thereby enabling the seeds to tolerate passage through the digestive system of cattle to a greater extent.

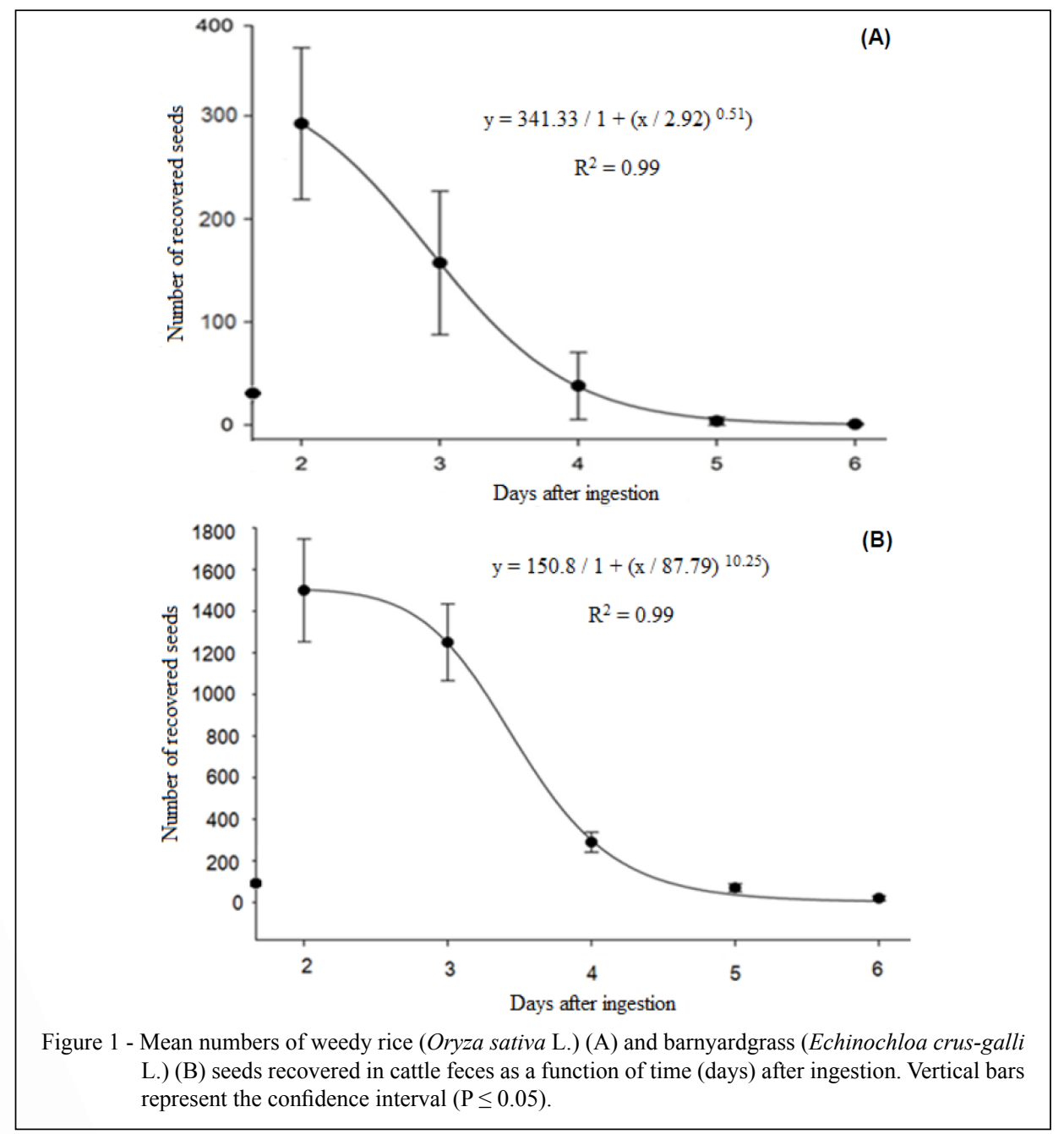

Ciência Rural, v.48, n.8, 2018. 
For both weed species, the highest values of recovered seeds were obtained 48 hours after ingestion: $60.8 \%$ of total weedy rice seeds and $59.5 \%$ of total barnyardgrass seeds. Moreover, during the first 3 days, $90.7 \%$ and $88.2 \%$ of weedy rice and barnyardgrass seeds were recovered, respectively. These results corroborated the findings of LISBOA et al. (2009), who reported that $43 \%$ of the total number of seeds of tough lovegrass (Eragrostis plana Nees) fed to cattle were recovered, $97.2 \%$ of which were recovered in the first 3 days.

The results showed that the seeds of both species passed through the digestive system on the $1^{\text {st }}$ day after ingestion and that seed recovery decreased from the $2^{\text {nd }}$ day of collection. The quantity recovered decreased markedly after 4 days of ingestion, and no weedy rice or barnyardgrass seeds were reported in the feces on the $6^{\text {th }}$ and $7^{\text {th }}$ days, respectively, thus establishing the minimum period of quarantine for these animals.

Barnyardgrass had a longer period of passage through the digestive system of animals, presumably because in endozoochory small seeds have a relatively long temporal dispersal period, whereas the dispersal of large seeds is concentrated in specific periods (MARIMON \& FELFILI, 2006). This difference may be explained in terms of seed weight, which is lower in barnyardgrass than in weedy rice and may affect mobility in the digestive system of animals, thereby determining the length of the retention period (GARDENER et al., 1993).
It should be noted that recovery values may be affected by specific animal and environmental characteristics because cattle are known to be affected by ambient temperature, ingested feed quality and quantity, and individual characteristics, which directly influence fecal excretion volume and frequency (FERREIRA et al., 2015). This in turn may affect seed recovery as a function of time (days) and even the total period of seed retention in the digestive system of animals.

In this study, we reported that, in the laboratory, the germination of seeds of both study species decreased significantly after passage through the digestive system. Compared with weedy rice and barnyardgrass controls, which showed $97 \%$ and $68 \%$ germination, respectively, germination rates of $51.3 \%$ and $62.5 \%$ were obtained for weedy rice and barnyardgrass seed that had passed through the digestive tract, respectively. A number of factors may have affected germination after passage through the digestive system of cattle, such as the physical processes of rumination; the action of ruminal microorganisms involved in food degradation and chemical action, when in contact with the abomasum; by-products of carbohydrate degradation, such as short-chain fatty acids; and ruminal temperature and internal $\mathrm{pH}$, which vary with the nature of the feed provided (OLIVEIRA et al., 2013).

For both weedy rice and barnyardgrass, emergence differed in soil and dung (Table 1). In dung, the emergence of both grass species was similar,

Table 1 - Weedy rice (Oryza sativa L.) and barnyardgrass (Echinochloa crus-galli L.) emergence (\%), in different substrates, with (recovered from cattle) and without (control) passage through the digestive system of cattle.

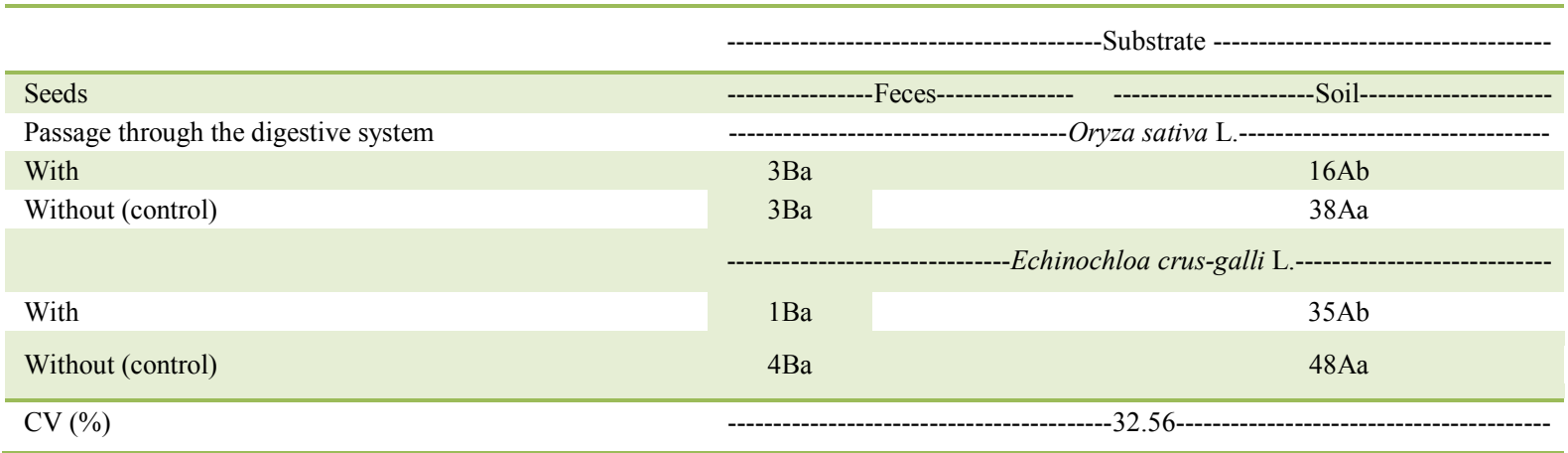

Means followed by different letters, uppercase in rows and lowercase in columns, differ according to the least significant difference Fisher test $(\mathrm{P}<0.05)$. 
regardless of seed passage through the digestive system, albeit lower than the emergence in soil. Seeds that had passed through the digestive system showed lower emergence in soil than seeds that had not passed through the digestive system. In dung, germination and emergence may be affected by the process of organic matter decomposition, enhanced by the action of abiotic factors, namely, temperature, humidity, rainfall, and light, and particularly by the action of insects and microorganisms such as fungi and bacteria (DEMINICIS et al., 2009b). Although, we reported that the coefficient of variation was high, according to the classification by PIMENTELGOMES (1987), this is a comprehensive classification that disregards experimental specificities, namely, the nature of the assay, thereby explaining a higher coefficient of variation because the present experiment was performed with animals and weeds, which use countless artifices that confer unevenness in the germination process (BRIGHENTI \& OLIVEIRA, 2011).

Despite the potential damage suffered by seeds during their passage through the digestive system of ruminants and in the decomposition of feces, they can germinate and colonize new areas. The high emergence percentage of seeds of weedy rice and barnyardgrass that passed through the digestive tract of cattle when placed in soil has important implications for the population dynamics of these weed species. Because tillage for paddy rice cultivation mainly involves a series of operations that disperses the topsoil layer, dung may be disrupted, thereby enhancing seed germination.

The findings of this study indicate that the ingestion of approximately three weedy rice or barnyardgrass plants with mature inflorescences (approximately 1000 weedy rice and 13818 barnyardgrass seeds) may result in the deposition of 509 weedy rice and 3233 barnyardgrass seeds in the area.

Considering that germination of both grass species was negatively affected by the digestion process, we estimate that approximately $24 \%$ (240.45) of weedy rice seeds and 6\% (829) of barnyardgrass seeds from the total seeds ingested by the cattle would still be potentially able to germinate. Although, when germinated in different substrates, we reported that seedling emergence of recovered seeds was lower in dung than in soil, 13 weedy rice and 11 barnyardgrass plants grew in dung. In soil, the situation would; therefore, be aggravated by the emergence of 79 new weedy rice and 770 barnyardgrass plants under the present study conditions, even after passage through the digestive system.
On the basis of this projection, cattle grazed within an area colonized by the species $O$. sativa and E. crus-galli, or even cattle purchased from other farms, must be carefully managed. Inflorescence emergence, and consequently the formation of mature seeds in plants directly available for grazing, can promote seed dispersal to new areas, causing new weed infestation if quarantine periods are not respected.

In this study; we therefore, provided a critical analysis of the population dynamics of $O$. sativa and E. crus-galli as a function of endozoochory. Although, the negative effects of passage through the digestive system of cattle on seed germination are beneficial for the management and control of these grass species, a proportion of the seeds remain viable after the digestive process, which is worrisome given by the potential colonization of new areas, particularly with respect to resistant biotypes of weedy rice and barnyardgrass.

\section{CONCLUSION}

The seeds of weedy rice and barnyardgrass showed potential endozoochory via cattle. Passage of the seeds of these species through the digestive system of cattle reduces their physiological quality, and their germination in dung was lower than that in soil. The quarantine period for animals that ingest weedy rice and barnyardgrass seeds should be at least 6 and 7 days, respectively.

\section{ETHICS AND BIOSAFETY CONSIDERATIONS}

The research protocol was reviewed and approved by the Universidade Federal do Pampa (UNIPAMPA), Committee of Ethics on the Use of Animals (approval number 029/2015).

\section{ACKNOWLEDGEMENTS}

The authors thank the Universidade Federal do Pampa (UNIPAMPA) and Departamento de Diagnóstico e Pesquisa Agropecuária (DDPA) for the facilities to accomplish this research.

\section{DECLARATION OF CONFLICTING OF INTERESTS}

The authors declared no potential conflicts of interest with respect to the research, authorship, and/or publication of this article.

\section{REFERENCES}

AGOSTINETTO, D. et al. Interference and economic weed threshold (Ewt) of barnyardgrass on rice as a function of crop plant arrangement. Planta Daninha, v. 28, p. 993-1003, 2010. Available 
from: $\quad<$ http://dx.doi.org/10.1590/S0100-83582010000500007>. Accessed: Jul. 4, 2018. doi: 10.1590/S0100-83582007000400007.

BENVENUTI, S. Weed seed movement and dispersal strategies in the agricultural environment. Weed Biology and Management, v. 7, n. 3, p. 141-157, 2007. Available from: $<$ https://doi.org/10.1111 /j.1445-6664.2007.00249.x>. Accessed: Jul. 4, 2018. doi: 10.1111/ j.1445-6664.2007.00249.

BRASIL. Ministério da Agricultura, Pecuária e Abastecimento. Regra para análise de sementes/Ministério da Agricultura, Pecuária e Abastecimento. Secretaria da Defesa Agropecuária Brasília: Mapa/ACS, 399p, 2009.

BRIGHENTI, A. M.; DE OLIVEIRA, M. F. Biologia de plantas daninhas. Embrapa Milho e Sorgo-Capítulo em livro técnicocientífico (ALICE), 2011.

DEMINICIS, B. B. et al. Natural dispersion of seeds: importance, classification and dynamics in tropical pastures. Archivos de zootecnia, v. 58, p. 35-58, 2009a.

DEMINICIS, B. B. et al. Germination of seeds in bovine dung. Archivos de zootecnia, v. 58, n. 221, p. 73-84, 2009b. 3-84 Available from: $<$ http://scielo.isciii.es/scielo.php?script $=$ sci arttext\&pid=S0004-5922009000100008\&lng=es\&nrm=iso $>$. Accessed: Jul. 04, 2018.

FERREIRA, S. et al. Characterization of bovine fecal. Revista Científica Eletrônica de Medicina Veterinária, v. 20, n. 1, p. 1-22, 2015.

FISCHER, S. F. et al. Experimental studies on the dispersal of plants and animals on sheep in calcareous grasslands. Journal of Applied Ecology, p. 1206-1222, 1996. Available from: <https:// www.jstor.org/stable/2404699>. Accessed: Jul. 4, 2018. doi: $10.2307 / 2404699$.

GARDENER, C. J. et al. Passage of legume and grass seeds through the digestive tract of cattle and their survival in feces. Journal of Applied Ecology, p. 63-74, 1993. Available from: < https://www.jstor.org/stable/2404271 >. Accessed: Jul. 4, 2018. doi: $10.2307 / 2404271$.

GALON, L. et al. Efficacy and selectivity of imidazolinone herbicides applied in flooded rice. RevistaBrasileira de Herbicidas, v. 11, n. 3, p. 284-295, 2012. Available from: $<$ https:// doi.org/10.7824/rbh.v11i3.163>. Accessed: Jul. 4, 2018. doi: 10.7824/rbh.v11i3.163.

LAMEGO, F. P. et al. Tolerance to Interference of Competing Plants and Suppressive Ability by Soybean Genotypes -II. Response of Yield Variables. Planta Daninha, v. 22, n. 4, p. 491498, 2004. Available from: <http://dx.doi.org/10.1590/S0100-
83582004000400002>. Accessed: Jul. 4, 2018. doi: 10.1590/ S0100-83582004000400002.

LISBOA, C. A. V. et al. Germination of capim-annoni-2 (Eragrostis plana Ness) seeds recovered in bovine feces. Revista brasileira de zootecnia: Brazilian jornal of animal Science, v. 38, n. 3, p. 405-410, 2009. Available from: <http://dx.doi.org/10.1590/S151635982009000300001>. Accessed: Jul. 4, 2018. doi: 10.1590/ S1516-35982009000300001.

MARIMON, B. S.; FELFILI, J. M. Chuva de sementes em uma floresta monodominante de Brosimum rubescens Taub. e em uma floresta mista adjacente no Vale do Araguaia, MT, Brasil. Acta Botanica Brasilica, v. 20, n. 2, p. 423-432, 2006.

MARQUES, J. B. B; DO COUTO, M. R. Ganho de peso bovino em resteva de arroz irrigado na safra de 2009/2010 na Embrapa Pecuária Sul. Embrapa Pecuária Sul, 2010.

MATZENBACHER, F. O. et al. Distribution and analysis of the mechanisms of resistance of barnyard grass (Echinochloa crusgalli) to imidazolinone and quinclorac herbicides. The Journal of Agricultural Science, v. 153, n. 06, p. 1044-1058, 2015. Available from: $<$ https://doi.org/10.1017/S0021859614000768P > . Accessed: Jul. 4, 2018. doi: 10.1017/S0021859614000768.

MENEZES, V. G. et al. Red rice (Oryza sativa) resistant to the herbicides imidazolinones. Planta Daninha, v.27, p.10471042, 2009. Available from: <http://dx.doi.org/10.1590/S010083582009000500018>. Accessed: Jul. 4, 2018. doi: 10.1590/ S0100-83582009000500018.

NETO, M. S. et al. Recovery of pasture seed ingested by ruminants. 1. Seed of six tropical pasture species fed to cattle, sheep and goats. Australian Journal of Experimental Agriculture, v. 27, n. 2, p. 239-246, 1987. Available from: <https://doi.org/10.1071/ EA9870239>. Accessed: Jul. 4, 2018. doi: 10.1071/EA9870239.

OCUMPAUGH, W. R.; SWAKON, D. H. D. Simulating grass seed passage through the digestive system of cattle: A laboratory technique. Crop science, v. 33, n. 5, p. 1084-1090, 1993. Available from: <https://dl.sciencesocieties.org/publications/ cs/abstracts/33/5/CS0330051084>. Accessed: Jul. 4, 2018. doi: 10.2135/cropsci1993.0011183X003300050041.

OLIVEIRA, V. et al. Chemical and physiological characteristics of rumen fermentation in grazing cattle - Review. Revista Científica Eletrônica de Medicina Veterinária, v. 20, n. 1, p. 1-21, 2013.

PIMENTEL-GOMES, F. Curso de estatística experimental. São Paulo, 466 p, 1987. SOCIEDADE SUL BRASILEIRA DE ARROZ IRRIGADO [SOSBAI]. Arroz irrigado: recomendações Técnicas da Pesquisa para o Sul do Brasil. Bento Gonçalves: SOSBAI, p. 10-11, 2016. 